\title{
Occupant Decision Making in Office Building Fire Emergencies: Experimental Results
}

\author{
WENDY L. SAUNDERS \\ Department of Industrial Sciences. \\ Swinburne University of Technology \\ PO Box 218 \\ Hawthorn 3122, Victoria, Australia
}

\begin{abstract}
This report examines the results from a methodology that uses a film and accompanying questionnaire to collect data on decision making during the early stages of an office building fire emergency. The film presents a credible modern office scenario and simulates certain physical and social cues, associated with a developing office fire emergency. It pauses briefly after the presentation of each cue and participants are requested to scale the probability of doing certain actions on a multi-stage questionnaire.

The results from the study indicate that there is validity in this technique of data collection, as significant discrimination is evident in the participants' response to the cues presented. Nevertheless, the preferred behavioural choices of the occupants, in response to cues associated with a building fire emergency, indicates a need for caution in the assessment of the time taken to evacuate a building. Even when the cues were clear indications of a fire, the preferred behaviour of the respondents, was to alert and assist others, rather than immediately evacuate the building.
\end{abstract}

KEY WORDS: building evacuation, emergency decision making, fire safety science, human behaviour in fires, office building fires 


\section{INTRODŨCTION:}

To develop sound models that predict occupant decision making in office building fire emergencies, access to large amounts of reliable and valid data is necessary. Serious office building fires are relatively rare occurrences when compared to fires in residential, entertainment and industrial occupancies. If controlled experiments and simulations can be developed to collect dependable data on occupant decision making, a number of problems can be solved. Large amounts of data can be generated without exposing the participants to serious risk and issues such as the effects of time delay on subjective recall (associated with collection of decision making data from real fires), can be controlied.

Building fire emergencies differ from everyday situations in two important ways. Firstly, there is generally much more at stake in terms of the survival of occupants and loss or damage to property. Secondly, the amount of time available to make a choice before certain options are lost, can be severely limited. The behaviour of occupants in the early, often ambiguous stages of the fire, is an important determinant of the time they take to evacuate the building. However, it is very difficult to collect reliable data on the decision making behaviour during this stage. Two sources of information on this behaviour are:

i) Interviews, questionnaires and case studies from actual building fire emergencies.

ii) Experiments that try to recreate or simulate, building fire emergency situations.

Most of the information on the early ambiguous stage, provided by interviews, questionnaires and case studies from building fires, is of limited value. Accounts of those involved can be distorted by the effects of the delay in time between the event and its recall, as well as by the physical and emotional stresses on the individual during the later stages of the emergency. To recreate a building fire emergency situation in the laboratory, in order to measure the decision making responses creates its own problems. There are the ethical problems associated with placing people in experimental situations which are designed to create fear and there are the problems associated with trying to reproduce the complexities of an emergency in the laboratory.

This report examines the results from a methodology that used a film and accompanying questionnaire to collect data on decision making during the early stages of an office building fire emergency. The film presented a credible modern office scenario and simulated certain physical and social cues associated with a developing office fire emergency. The cues in the version of the film reported in this study, included a brief power failure, a building alarm and the presence of smoke and flames. The film paused briefly after the presentation of each cue and participants were requested to scale the probability of doing certain actions on a multistage questionnaire.

\section{METHOD:}

Participants

The 243 voluntary participants in this study comprised 159 adult students from postsecondary Melbourne institutions and 84 office workers from government organisations and private companies in Melbourne and Canberra (TABLE 1). Because participants were drawn from many different sources, group sizes ranged from 5 to 25 members 


\begin{tabular}{|l|c|c|}
\multicolumn{1}{|c|}{$\begin{array}{c}\text { SUBJECT GROUP } \\
(\mathbf{N}=\mathbf{2 4 3})\end{array}$} & MALE & FEMALE \\
\hline Office Workers & 59 & 25 \\
Tertiary Students & 84 & 75 \\
\hline TOTAL & 143 & 100 \\
\hline
\end{tabular}

Instruments

1. The Film:

The purpose of the film is to present participants with an ambiguous situation, which they must cognitively interpret, in terms of the information given. They were not told that the exercise was designed to collect data on emergency decision making. The film contained cues that are typical of a developing office building fire emergency. These cues acted as the stimuli for decision making choices in an accompanying questionnaire. Actors took the part of office staff involved in the development of the building fire scenario. The film paused when an actor experienced one of the cues, to enable respondents (the participants) to complete the questionnaire.

The film is set in a modern high rise office building in Melbourne. The floor on which the action takes place has both open plan work areas and single offices. The script was given to a number of experts in the field of building fire emergencies (fire safety managers and operational fire fighters) to ensure credibility and validity. It was based on a number of real office building fire incidents in Australian cities. To establish a plausible fire scenario in a building equipped with modern detection, alarm and suppression systems (smoke detectors, EWIS system and sprinklers), the script calls for the temporary disconnection of the building's systems at the main fire panel, by workmen involved in cutting and welding on one of the floors. The fire is caused by an electrical fault in a photocopying room, whilst the detection system is disabled. The length of each version of the film (including breaks to answer the questionnaire) is about fifteen minutes.

The cues presented in this version of the film were:

(i) The "control" cue, which is a computer screen "freezing".

(ii) The first stage ("Alert" = "Beep" tone) of the building's two stage alarm system.

(iii) Smoke and flames coming from a fire (discovered by one of the "occupants") in a photocopying room.

In an attempt to control the point of view of the respondents to the questionnaire, each cue was experienced by only one of the actors. 
The questionnaire comprised three identical lists of thirty six actions. Accompanying each of the thirty six actions was a scale on which each respondent ticked the probability of doing that particular action (example shown in FIGURE 1). The thirty six actions represented those cognitively possible for occupants of an office building during a fire emergency (Appendix). They cover seven categories of behaviour described by earlier researchers in human behaviour in building fires.

Respondents were requested to tick a box for every action and to complete one list during each pause in the film. They were under time pressure to complete each section. Three minutes were allowed for completion in the first break and ninety seconds for subsequent breaks. To maintain consistency of instructions and administration, the author conducted all group experimental sessions. Because of the number of actions on the questionnaire, its repetitive nature and to prevent the effects of boredom with the procedure, it was decided to keep the number of cues (and hence breaks in the film) to a maximum of three. The film has been edited into a number of versions each containing different cues.

FIGURE 1. EXAMPLE OF THE SCALE USED FOR THE SUBJECTIVE PROBABILITY ASSESSMENT OF PERFORMING AN ACTION.

16. Contact other colleagues to report the situation.

UNLIKELY

LIKELY

\begin{tabular}{|l|l|l|l|l|}
\hline Extremely & Quite & Uncertain & Quite & Extremely \\
\hline
\end{tabular}

Procedure

The participants were shown a version (Version \# 2) of the film, which contains four cues and four subsequent breaks (Table 2). Cues 3 and 4 were treated as one cue with only one break at the end of the film. The participants were requested to fill in the questionnaire after cues 1,2 and 4.

TABLE 2: $\quad$ CUES IN VERSION \#2 OF THE DECISION MAKING FILM

\begin{tabular}{|c|c|c|c|}
\hline Cue 1 & \multicolumn{1}{|c|}{ Cue 2 } & Cue 3 & Cue 4 \\
\hline Computer breakdown & $\begin{array}{l}\text { First Stage ("Alert" } \\
\text { Signal) of Building } \\
\text { Alarm System }\end{array}$ & $\begin{array}{l}\text { Smoke coming out } \\
\text { beneath closed } \\
\text { photocopier door. }\end{array}$ & $\begin{array}{l}\text { Opening the } \\
\text { photocopier door to } \\
\text { flames. }\end{array}$ \\
\hline
\end{tabular}




\section{RESULTS:}

To encode the responses for statistical analysis, each choice on the five point probability scale was given a discrete numerical value (Table 3 ).

TABLE 3: NUMERICAL VALUES ASSIGNED TO THE FIVE POINT SCALE

\begin{tabular}{|c|c|c|c|c|}
\hline $\begin{array}{c}\text { Extremely } \\
\text { Unlikely }\end{array}$ & $\begin{array}{c}\text { Quite } \\
\text { Unlikely }\end{array}$ & Uncertain & $\begin{array}{c}\text { Quite } \\
\text { Likely }\end{array}$ & $\begin{array}{c}\text { Extremely } \\
\text { Likely }\end{array}$ \\
\hline-2 & -1 & 0 & +1 & +2 \\
\hline
\end{tabular}

1. Analysis of Variance:

A one-way analysis of variance was used to make simultaneous comparisons between the calculated means of each action, in response to the cues presented. This procedure determines the statistical significance of the relationship between the experimental variables. It is a measure of the degree of discrimination between the cues, exhibited by respondents to the questionnaire. The independent variables are the cues and the thirty six actions represent the dependent variables. F ratios and probabilities were computed for each action. At the 0.05 level of significance the majority of actions discriminated between one or more of the cues. This indicates that the participants were responding to the office fire simulation, portrayed in the film as they selected different probabilities for each action as a function of the cue. Only five actions failed to demonstrate any discrimination between cues. They were:

19. Turn off equipment.

22. Wait for a colleague's assistance to evacuate the area.

25. Wait for the assistance of the fire brigade to evacuate the area.

26. Wait for the floor warden's assistance to evacuate the area.

35. Remain in the area until the fire brigade arrives. 
TABLE 4. DESCRIPTIVE STATISTICS FOR THE 36 ACTIONS OVER THE 3 CUES

\begin{tabular}{|c|c|c|c|c|c|c|}
\hline \multirow{3}{*}{$\begin{array}{c}\mathbf{N}=\mathbf{2 4 3} \\
\begin{array}{c}\text { Action } \\
\text { No }\end{array}\end{array}$} & \multicolumn{6}{|c|}{ CUE } \\
\hline & \multicolumn{2}{|c|}{ Computer Breakdown } & \multicolumn{2}{|c|}{ Alarm } & \multicolumn{2}{|c|}{ Smoke and Flames } \\
\hline & Mean & $\begin{array}{l}\text { Standard } \\
\text { Deviation }\end{array}$ & Mean & $\begin{array}{l}\text { Standard } \\
\text { Deviation }\end{array}$ & Mean & $\begin{array}{l}\text { Standard } \\
\text { Deviation }\end{array}$ \\
\hline 1 & 0.18 & 1.22 & -1.17 & 1.04 & -1.86 & 0.60 \\
\hline 2 & 0.63 & 1.07 & -1.18 & 1.02 & -1.86 & 0.61 \\
\hline 3 & 0.63 & 1.06 & -1.09 & 1.10 & -1.77 & 0.78 \\
\hline 4 & 0.53 & 1.14 & -1.08 & 1.10 & -1.81 & 0.66 \\
\hline 5 & 0.65 & 1.28 & -1.11 & 1.08 & -1.86 & 0.55 \\
\hline 6 & 0.63 & 1.19 & -1.09 & 1.05 & -1.85 & 0.54 \\
\hline 7 & 0.67 & 1.16 & 0.71 & 1.25 & -0.95 & 1.50 \\
\hline 8 & 0.49 & 1.22 & 0.47 & 1.27 & -0.93 & 1.49 \\
\hline 9 & 0.04 & 1.45 & 0.21 & 1.38 & -0.33 & 1.69 \\
\hline 10 & 0.10 & 1.28 & 0.23 & 1.32 & -0.33 & 1.62 \\
\hline 11 & 0.07 & 1.31 & 0.56 & 1.28 & -0.53 & 1.58 \\
\hline 12 & 0.04 & 1.42 & 0.07 & 1.34 & 0.95 & 1.36 \\
\hline 13 & -0.87 & 1.30 & -0.30 & 1.35 & 1.10 & 1.35 \\
\hline 14 & -1.07 & 1.25 & -0.35 & 1.34 & 1.62 & 0.84 \\
\hline 15 & -0.33 & 1.45 & 0.23 & 1.38 & 1.40 & 0.96 \\
\hline 16 & 0.01 & 1.34 & 0.55 & 1.24 & 1.41 & 0.99 \\
\hline 17 & -0.92 & 1.22 & -0.9 & 1.22 & 0.05 & 1.60 \\
\hline 18 & -0.04 & 1.51 & 0.12 & 1.35 & -0.35 & 1.51 \\
\hline 19 & -0.26 & 1.37 & 0.04 & 1.31 & -0.15 & 1.54 \\
\hline 20 & -0.06 & 1.23 & -0.50 & 1.18 & -0.94 & 1.17 \\
\hline 21 & 0.00 & 1.38 & 0.61 & 1.10 & 1.23 & 0.98 \\
\hline 22 & -0.60 & 1.31 & -0.29 & 1.21 & -0.48 & 1.27 \\
\hline 23 & 0.66 & 1.32 & 0.04 & 1.38 & -0.90 & 1.38 \\
\hline 24 & -0.61 & 1.34 & -0.12 & 1.24 & 0.66 & 1.40 \\
\hline 25 & -0.86 & 1.25 & -0.77 & 1.07 & -0.84 & 1.22 \\
\hline 26 & -0.68 & 1.34 & -0.19 & 1.29 & -0.29 & 1.38 \\
\hline 27 & -0.37 & 1.48 & 0.48 & 1.29 & 1.20 & 1.00 \\
\hline 28 & -0.59 & 1.43 & 0.19 & 1.36 & 0.77 & 1.23 \\
\hline 29 & -0.59 & 1.39 & -0.05 & 1.35 & 0.03 & 1.34 \\
\hline 30 & -0.25 & 1.47 & 0.42 & 1.27 & 1.00 & 0.99 \\
\hline 31 & -0.40 & 1.41 & 0.68 & 1.21 & 1.15 & 0.95 \\
\hline 32 & -0.91 & 1.21 & -0.39 & 1.24 & 0.29 & 1.36 \\
\hline 33 & -0.99 & 1.15 & -0.63 & 1.16 & -0.50 & 1.33 \\
\hline 34 & -0.70 & 1.33 & -0.34 & 1.35 & 0.47 & 1.43 \\
\hline 35 & -0.77 & 1.27 & -0.86 & 1.15 & -0.90 & 1.20 \\
\hline 36 & -0.89 & 1.27 & -0.65 & 1.21 & -0.21 & 1.45 \\
\hline
\end{tabular}

2. Arithmetic Means of the Actions

The calculated means for each action (TABLE 4), give an indication of the likelihood that participants in the experiment would choose the individual action in response to the cue presented. The standard deviations illustrate the spread of responses on the five point numerical scale depicted in TABLE 3. It was deemed that most people would be quite 
likely to choose an action in response to the particular cue, when the mean for the action approaches 0.70 . Conversely, it was deemed that it would be urilikely that most people would choose the action when its mean approaches - 0.70 . A large number of "uncertain" responses or responses that were equally distributed between likely and unlikely, resulted in individual means approaching zero. Table 5 shows the most likely actions in response to each cue, whereas Table 6 depicts the least likely actions in response to cues.

TABLE 5: MOST LIKELY ACTIONS IN RESPONSE TO EACH CUE $(\mathrm{N}=243)$

\begin{tabular}{|c|c|c|c|}
\hline Cue & Action & Category & Mean \\
\hline $\begin{array}{l}\text { Computer } \\
\text { Breakdown }\end{array}$ & $\begin{array}{l}\text { Ask someone else nearby for } \\
\text { more information. } \\
\text { Continue eating/drinking } \\
\text { (tea/lunch break). }\end{array}$ & $\begin{array}{l}\text { SEEK FURTHER } \\
\text { INFORMATION / } \\
\text { INVESTIGATE } \\
\text { CONTINUE NORMAL } \\
\text { ACTIVITIES }\end{array}$ & $\begin{array}{l}0.67 \\
0.65\end{array}$ \\
\hline $\begin{array}{l}\text { First Stage } \\
\text { Alarm }\end{array}$ & $\begin{array}{l}\text { Ask someone else nearby for } \\
\text { more information. } \\
\text { Move towards an exit. }\end{array}$ & $\begin{array}{l}\text { SEEK FURTHER } \\
\text { INFORMATION / } \\
\text { INVESTIGATE } \\
\text { EVACUATION } \\
\end{array}$ & $\begin{array}{l}0.71 \\
0.68 \\
\end{array}$ \\
\hline $\begin{array}{l}\text { Smoke and } \\
\text { Flames }\end{array}$ & $\begin{array}{l}\text { Activate the fire alarm (break the } \\
\text { glass). } \\
\text { Contact other colleagues to } \\
\text { report the situation. } \\
\text { Contact the floor warden to } \\
\text { report the situation. } \\
\text { Check the area for the presence } \\
\text { of other people. } \\
\text { Assist others to leave the area. } \\
\text { Move towards an exit. } \\
\text { Telephone the fire brigade to } \\
\text { report the situation. } \\
\text { Assist (comfort, first aid) others. } \\
\text { Contact the switchboard to report } \\
\text { the situation. } \\
\text { Leave the area immediately by } \\
\text { the emergency exit. }\end{array}$ & $\begin{array}{l}\text { ALERT / WARN OTHERS } \\
\text { ALERT / WARN OTHERS } \\
\text { ALERT / WARN OTHERS } \\
\text { PROTECTIVE } \\
\text { PROCEDURES } \\
\text { EVACUATE } \\
\text { EVACUATE } \\
\text { ALERT / WARN OTHERS } \\
\text { PROTECTIVE } \\
\text { PROCEDURES } \\
\text { ALERT / WARN OTHERS } \\
\text { EVACUATE }\end{array}$ & $\begin{array}{l}1.62 \\
1.41 \\
1.40 \\
1.23 \\
1.20 \\
1.15 \\
1.10 \\
1.00 \\
0.95 \\
0.77\end{array}$ \\
\hline
\end{tabular}


TABLE 6: LEAST LIKELY ACTIONS IN RESPONSE TO THE CUES $(\mathrm{N}=243)$

\begin{tabular}{|c|c|c|c|}
\hline Cue & Action & Category & Mean \\
\hline $\begin{array}{l}\text { Computer } \\
\text { Breakdown }\end{array}$ & $\begin{array}{l}\text { Activate the fire alarm )break the } \\
\text { glass). } \\
\text { Attempt to put out the fire by } \\
\text { smothering, using a bucket of } \\
\text { water, etc. } \\
\text { Collect own or others personal } \\
\text { property. } \\
\text { Attempt to fight the fire with a } \\
\text { fire extinguisher. } \\
\text { Search for things to fight the fire } \\
\text { with. } \\
\text { Telephone the fire brigade to } \\
\text { report the situation. } \\
\text { Wait for the assistance of the fire } \\
\text { brigade to evacuate the area. } \\
\text { Remain in the area until the fire } \\
\text { brigade arrives. }\end{array}$ & $\begin{array}{l}\text { ALERT / WARN OTHERS } \\
\text { FIRE FIGHTING } \\
\text { PROTECTIVE } \\
\text { PROCEDURES } \\
\text { FIRE FIGHTING } \\
\text { FIRE FIGHTING } \\
\text { ALERT / WARN OTHERS } \\
\text { WAIT FOR ASSISTANCE } \\
\text { PROTECTIVE } \\
\text { PROCEDURES }\end{array}$ & $\begin{array}{l}-0.92 \\
-0.91 \\
-0.89 \\
-0.87 \\
-0.86 \\
-0.77\end{array}$ \\
\hline $\begin{array}{l}\text { First Stage } \\
\text { Alarm }\end{array}$ & $\begin{array}{l}\text { Continue with computer work. } \\
\text { Continue with office paper work. } \\
\text { Continue eating/drinking } \\
\text { (tea/lunch break). } \\
\text { Continue meeting with others. } \\
\text { Continue a telephone } \\
\text { conversation. } \\
\text { Continue deliveries/errands. } \\
\text { Remain in the area until the fire } \\
\text { brigade arrives. } \\
\text { Wait for the assistance of the fire } \\
\text { brigade to evacuate the area. }\end{array}$ & $\begin{array}{l}\text { CONTINUE NORMAL } \\
\text { ACTIVITIES } \\
\text { CONTINUE NORMAL } \\
\text { ACTIVITIES } \\
\text { CONTINUE NORMAL } \\
\text { ACTIVITIES } \\
\text { CONTINUE NORMAL } \\
\text { ACTIVITIES } \\
\text { CONTINUE NORMAL } \\
\text { ACTIVITIES } \\
\text { CONTINUE NORMAL } \\
\text { ACTIVITIES } \\
\text { WAIT FOR ASSISTANCE } \\
\text { WAIT FOR ASSISTANCE }\end{array}$ & $\begin{array}{l}-1.17 \\
-1.18 \\
-1.11 \\
-1.09 \\
-1.08 \\
-1.09 \\
-0.86 \\
-0.77\end{array}$ \\
\hline
\end{tabular}




\begin{tabular}{|c|c|c|c|}
\hline Cue & Action & Category & Mean \\
\hline $\begin{array}{l}\text { Smoke and } \\
\text { Flames }\end{array}$ & $\begin{array}{l}\text { Continue with computer work. } \\
\text { Continue with office paper work. } \\
\text { Continue eating/drinking } \\
\text { (tea/lunch break). } \\
\text { Continue deliveries/errands. } \\
\text { Continue meeting with others. } \\
\text { Continue a telephone } \\
\text { conversation. } \\
\text { Ask someone else nearby for } \\
\text { more information. } \\
\text { Search for a colleague for more } \\
\text { information. } \\
\text { Remain in the area until someone } \\
\text { else arrives. } \\
\text { Remain in the area until the fire } \\
\text { brigade arrives. } \\
\text { Answer a ringing telephone } \\
\text { Wait for the assistance of the fire } \\
\text { brigade to evacuate the area. }\end{array}$ & $\begin{array}{l}\text { CONTINUE NORMAL } \\
\text { ACTIVITIES } \\
\text { CONTINUE NORMAL } \\
\text { ACTIVITIES } \\
\text { CONTINUE NORMAL } \\
\text { ACTIVITIES } \\
\text { CONTINUE NORMAL } \\
\text { ACTIVITIES } \\
\text { CONTINUE NORMAL } \\
\text { ACTIVITIES } \\
\text { CONTINUE NORMAL } \\
\text { ACTIVITIES } \\
\text { SEEK FURTHER } \\
\text { INFORMATION / } \\
\text { INVESTIGATE } \\
\text { SEEK FURTHER } \\
\text { INFORMATION / } \\
\text { INVESTIGATE } \\
\text { PROTECT } \\
\text { FIRE FIGHTING } \\
\text { SEEK FURTHER } \\
\text { INFORMATION / } \\
\text { INVESTIGATE } \\
\text { WAIT FOR ASSISTANCE }\end{array}$ & $\begin{array}{l}-1.86 \\
-1.86 \\
-1.86 \\
-1.85 \\
-1.77 \\
-1.81 \\
-0.95\end{array}$ \\
\hline
\end{tabular}

Significance of the Means:

Using the means as a guide, all groups displayed a polarisation of responses as the film progressed. For cue 3 (smoke and flames), there are very few "uncertain" responses, the means for individual actions tend towards the extremes of the scale (extremely likely or extremely unlikely) and the spread (Standard Deviations), of responses is less. Using the descriptive classification (Appendix), the most likely and least likely categories of actions in response to each cue, are shown in Table 7. The entries under the No. column refer to the number of actions from that category (derived from Tables 5 and 6). 
TABLE 7: DESCRIPIIVE SUMMARY OF CHOICE IN RESPONSE TO CUES PRESENTED $\quad(\mathrm{N}=243)$

\begin{tabular}{|c|c|c|c|c|c|c|}
\hline & $\begin{array}{c}\text { Cue 1 } \\
\text { Computer } \\
\text { Breakdown }\end{array}$ & No. & $\begin{array}{c}\text { Cue 2 } \\
\text { First Stage } \\
\text { ("Alert" Signal) } \\
\text { of Building } \\
\text { Alarm System }\end{array}$ & No. & $\begin{array}{l}\text { Cue } 3 \\
\text { Opening the } \\
\text { photocopier } \\
\text { door to smoke } \\
\text { and flames. }\end{array}$ & No. \\
\hline Most Likely & $\begin{array}{l}\text { Continue } \\
\text { Normal } \\
\text { Activities } \\
\\
\text { Investigate }\end{array}$ & 1 & $\begin{array}{l}\text { Investigate } \\
\text { Evacuate }\end{array}$ & $\begin{array}{l}1 \\
1\end{array}$ & $\begin{array}{l}\text { Alert / Warn } \\
\text { Others } \\
\text { Evacuate } \\
\text { Protective } \\
\text { Procedures }\end{array}$ & $\begin{array}{l}5 \\
3 \\
2\end{array}$ \\
\hline Least Likely & $\begin{array}{l}\text { Fire Fighting } \\
\text { Alert / Warn } \\
\text { Others } \\
\text { Wait for } \\
\text { Assistance } \\
\text { Protective } \\
\text { Procedures }\end{array}$ & $\begin{array}{l}3 \\
2\end{array}$ & $\begin{array}{l}\text { Continue } \\
\text { Normal } \\
\text { Activities } \\
\text { Wait for } \\
\text { Assistance }\end{array}$ & 2 & $\begin{array}{l}\text { Continue } \\
\text { Normal } \\
\text { Activities } \\
\text { Protective } \\
\text { Procedures } \\
\text { Wait for } \\
\text { Assistance } \\
\text { Investigate } \\
\text { Fire Fighting }\end{array}$ & $\begin{array}{l}1 \\
1 \\
3 \\
1\end{array}$ \\
\hline
\end{tabular}

\section{DISCUSSION:}

The point of view controlled by the film and adopted by respondents, was that of an individual decision maker. Statistical analysis indicates that the participants responded to the cues presented in the film, with polarisation of decisional choice towards extreme values (extremely likely or extremely unlikely) as the cues gave more information about the situation (smoke and flames give more information about a fire than does a building alarm). Although this polarisation may be due in part to familiarity with the questionnaire as the experiment progressed, it is more likely to be a product of the participants' increasing awareness of the development of a building fire emergency. The participants in this experiment had a degree of familiarity with the two stage building alarm system, presented as a cue in the film, as this type of alarm was installed in all of the occupancies used in this study. 


\section{SUMMARY:}

1. Response to the ambiguous cues (computer breakdown and building alarm). The majority of respondents chose to continue with what they were doing (in the case of the computer breakdown) or investigate the situation in response to the building alarm. The means for these behaviours were lower than those for behaviours in response to smoke and flames. Least probable behaviours in response to these cues, were fire fighting, alerting others and protecting (to the computer breakdown), and continuing normal activities in response to the building alarm.

2. Response to smoke and flames. The presence of smoke and flames - a clear sign of a fire - resulted in the choices of alerting others, evacuation and protective procedures. Note that the most common choice in response to this cue was that of alerting and assisting others. Concern for others (altruism) appears to take precedence over evacuation of self. The means for these choices tended towards extremely likely, indicating a consensus in response. Continuing normal activities, investigation and remaining in the area, were the least probable actions in response to the presence of smoke and flames.

3. Delay in the time to evacuate. The preferred behaviours evident in the responses to the building alarm and the presence of smoke and flames, may explain the time delay in evacuation, observed in many building fire emergencies. This delay could be due, firstly, to non-informative warning systems, as used in the film. The participants in the experiment, like building occupants in an emergency, need clear information in order to act appropriately. Without this information, much time will be lost in investigation and conferring with others, to establish a clearer picture of the situation. A second explanation for the time delay could be the degree of altruism. Even when the cues are clear indications of a fire, the preferred behaviour of the respondents, was to alert and assist others, rather than immediately evacuate the building.

4. Fire fighting and waiting for assistance. In all instances, the respondents demonstrated a reluctance to fight the fire or wait for assistance in a building fire emergency.

\section{RECOMMENDATIONS:}

1. Caution is needed in the assessment of time taken to evacuate a building in an emergency. It is an uncomplicated task, to calculate the time taken for occupants to evacuate buildings, once the decision to evacuate is made. This time can be measured during routine evacuation drills. Without preparation or forewarning, it is extremely difficult to estimate the total time, including the time spent in other activities, to evacuate a building, in an emergency. This time must include the time from when the occupants perceive the early signs of an emergency. As observed in the results of this experiment, other behavioural options may take precedence over building evacuation in an emergency.

2. Informative warning systems with provision for clear, up to date and accurate information as to the nature, severity and location of a building emergency, would reduce the time spent by occupants in authenticating the situation. Instructions for appropriate behaviour reduces the occupants' decision making time and consequently the time spent on activities other than evacuation, before untenable conditions develop.

3. Statistical analysis is in progress to develop a mathematical model that confirms underlying structural consistencies in response and provides numerical information on connections between sequences of actions. Other versions of the film, that contain different cues, will also be used to collect data on occupant decision making in office building fire emergencies. 


\title{
ACKNOWLEDGEMENTS:
}

The work reported in this paper is funded by an Australian Postgraduate Research Award (Industry) and BHP Research, Melbourne, Australia.

\section{APPENDIX: CLASSIFICATION OF ACTIONS}

\author{
A Continue Normal Activities \\ 1. Continue with computer work. \\ 2. Continue with office paper work. \\ $3 . \quad$ Continue meeting with others. \\ 4. Continue a telephone conversation. \\ 5. Continue eating/drinking (tea/lunch break). \\ 6. Continue deliveries/errands.
}

\section{B Seek Further Information/Investigation}

7. Ask someone else nearby for more information.

8. Search for a colleague for more information.

9. Telephone the floor warden for more information.

10. Search for the source of the unusual signs.

11. Look out of a door or window to investigate.

23. Answer a ringing telephone.

\section{Alert/Warn Others}

12. Contact the switchboard to report the situation.

13. Telephone the fire brigade to report the situation.

14. Activate the fire alarm (break the glass).

15. Contact the floor warden to report the situation.

16. Contact other colleagues to report the situation.

\section{Protective Procedures}

17. Collect own or other's personal property.

18. Secure computer files, disks or documents.

19. Turn off equipment.

20. Remain in the area until someone else arrives.

21. Check the area for the presence of other people.

30. Assist (comfort, first aid) others.

34. Close doors or windows.

\section{E Wait for Assistance}

22. Wait for a colleague's assistance to evacuate the area.

24. Telephone the floor warden for assistance to evacuate the area.

25. Wait for the assistance of the fire brigade to evacuate the area.

26. Wait for the floor warden's assistance to evacuate the area.

\section{F Evacuate}

27. Assist others to leave the area.

28. Leave the area immediately by the emergency exit.

29. Leave the area immediately by the most familiar route.

31. Move towards an exit.

\section{G Fire Fighting}

32. Attempt to fight the fire with a fire extinguisher.

33. Attempt to put out the fire by smothering, using a bucket of water, etc.

35. Remain in the area until the fire brigade arrives.

36. Search for things to fight the fire with. 